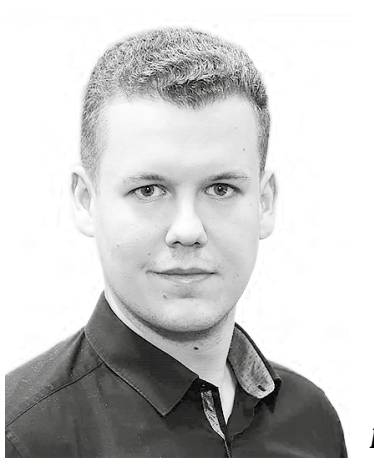

\title{
ТЕОРЕТИКО-ПРАВОВИЙ АНАЛІЗ ВИЗНАЧЕННЯ ПОНЯТТЯ «КОМПЛАЕНС» ТА ЙОГО ВИДІВ
} Академія управління персоналом» (м. Київ)

МОЖАРОВСЬКИЙ Микита Юрійович - аспірант кафедри господарського права, трудового права та цивільно-правових дисциплін ПрАТ «Вищий навчальний заклад «Міжрегіональна

УДК 346.3

DOI 10.32782/LAW.UA.2021.2.21

Статья посвящена теоретико-правовому анализу понятия «комплаенс» в зависимости от его видовых признаков, лежащих в основе отраслевой принадлежности как наиболее распространеннъхх и широко применяемых механизмов внутреннего контроля предприятия в современньх условиях в Украине.

Ключевъие слова: комплаенс, комплаенсриски, коплаенс-процедурьи, антикоррупционнылй комплаенс, налоговъий комплаенс, корпоративный комплаенс, трудовой комплаенс, комплаенс-нормъ, комплаенс-контроль, субъекты хозяйствования.

Постановка проблеми у загальному вигляді

Загальновідомим фактом, що підтримується переважною більшістю як науковців так і практиків, є пряма залежність очікуваної рентабельності (що зазвичай закладається в техніко-економічні показники бізнесу) та можливих ризиків при впровадженні бізнесу.

Маємо констатувати, на жаль, що наявність як суб’єктивних так і об’єктивних чинників, що існують у сучасних умовах в Україні, мають враховуватись при визначенні такого співвідношення. До таких чинників, що впливають на алеаторність бізнесу ми відносимо нестабільність політичної ситуації, вплив корупційних ризиків, кризові явища в економіці, у тому числі вплив пандемії, спричиненої Covid-19, девальвація національної валюти та, в першу чергу, війна на сході України.
Не дивно, що український ринок останнім часом повністю або частково залишила або залишає велика кількість іноземних компаній таких як Chevron, ExxonMobil, Clifford Chance, Wizz Air Ukraine, Gide Loyrette Nouel.

Запобігти зазначеному можуть заходи спрямовані на підвищення культури корпоративного управління, до яких, у першу чергу, треба віднести комплаєнс-заходи, що спрямовані на дотримання загально прийнятих норм, антикорупційного законодавства, правил, що $є$ загально прийнятими у відповідній сфері господарювання, що в сукупності мають забезпечувати стабільність діяльності в сучасних умовах та невілювання негативних факторів.

Комплаєнс-заходи, що широко застосовуються впродовж тривалого часу компаніями економічно розвинутих країн починають впроваджуватись вітчизняними суб'єктами господарювання у своїй діяльності та слугують важливим елементом інтеграції українських компаній в світову економіку.

Зв'язок вказаної проблеми із важливими науковими та практичними завданнями

Про важливе значення комплаєнсу в контексті соціально-економічного розвитку сучасного життя свідчать озвучені в Давосі (Швейцарія) на Всесвітньому економічному форумі тези про те, що комплаєнс як активне застосування внутрішнього 


\section{Цивільне, підприсмницьке, господарське та трудове право}

контролю належить до таких важливих сфер покращення економіки, як боротьба 3 корупцією, скорочення бюрократії та доступність кредитування.

Акцентування уваги на важливості комплаєнсу для сталого розвитку економіки спонукає до висновку про важливість існування таких складових у діяльності будь-якого комплаєнс-департаменту як попередня узгодженість нормативних документів та алгоритмів, що спрямовані на виявлення, ідентифікацію, оцінку та невілювання своєчасно встановлених ризиків.

3 огляду на зазначене, метою цієї статті є дослідження понятійно-категоріального апарату економіко-правових складових комплаєнсу у контексті видової приналежності як найбільш розповсюджених та широко застосовуваних механізмів внутрішнього контролю суб'єкта господарювання в сучасних умовах в Україні.

\section{Аналіз останніх досліджень i публікацій, у яких започатковано розв'язання цієї проблеми}

Поняття «комплаєнс», без перебільшення, є новим для української наукової думки. Спроба надати визначення поняттю комплаєнсу та його видам були присвячені роботи ряду вітчизняних та зарубіжних учених, таких як: Ю. Беляєв, Ю. Бондаренко, В. Гелеверя, С. Дж. Гріффіт, Ж. Іванова, А. Калініченко, Д. Малихін, Н. Москаленко, О. Морковкіна, А. Ніколаєва, О. Нєізвєстна, Д. Пєтров, В. Попондопуло, А. Правдива, Н. Рубцова , Річард Фієна, Т. Романчик, О. Франскевич, М. Хуторна, М. Шарамко, Т. Щерба та ін.

Виділення не вирішених раніше частин загальної проблеми, котрим присвячується означена стаття

Вочевидь, і це є логічним, комплаєнсзаходи можуть мати власну специфіку їх застосування у доволі широкому спектрі суспільно-економічних відносин. Цей спектр не обмежується сферами антикорупційної, податкової, корпоративної, трудової, а є доволі актуальним у застосуванні у сферах антимонопольної, інноваційної, інтелекту- альної власності, екології, технічного регулювання та стандартизації та ін.

\section{Виклад основного матеріалу дослідження і обгрунтування отриманих наукових результатів}

Термін «комплаєнс» (compliance) походить від англійського «to comply» (виконувати, відповідати певним вимогам, стандартам тощо). Відповідність законам, правилам і стандартам у сфері комплаєнса зазвичай стосується таких питань, як дотримання належних стандартів поведінки на ринку, управління конфліктами інтересів, справедливе ставлення до клієнтів і забезпечення сумлінного підходу при консультуванні клієнтів. До сфери комплаєнса відносяться також специфічні області, такі як:

- протидія легалізації доходів, отриманих злочинним шляхом, і фінансуванню тероризму;

- розробка документів і процедур, що забезпечують відповідність діяльності компанії з чинним законодавством;

- захист інформаційних потоків, протидія шахрайству і корупції, встановлення етичних норм поведінки співробітників і т. ін. [1].

Оксфордський словник англійської мови наводить наступне визначення зазначеного терміну: «комплаєнс» - діяльність, що відповідає встановленим вимогам чи вказівкам, або ж покора (англійською compliance is an action in accordance with a request or command, obedience) [2].

Кембріджський словник англійської мови наводить таке визначення цього терміна: комплаєнс - «дія у відповідності до запиту, правила чи вказівки» [3].

Міжнародна асоціація комплаєнсу (International Compliance Association) визначає поняття «комплаєнс» як здатність діяти відповідно до закону, набору правил та норм або встановлених вимог та внутрішніх процедур [4, с. 114].

Базельський комітет з банківського нагляду (2005 р.) визначає комплаєнс-ризик як ризик юридичних або регуляторних санкцій, матеріальних фінансових втрат або втрат репутації, від яких банк може 
постраждати через невиконання законів, нормативно-правових актів, правил, пов'язаних зі стандартами організації та кодексами поведінки, що застосовуються до їі банківської діяльності [5].

Варто звернути увагу на те, як визначають комплаєнс учені. Так, $\lambda$. Правдива дає визначення поняттю «комплаєнс» як етичній поведінці, законослухняності [6, с. 12].

Н. В. Москаленко зазначає, що «комплаєнс» - це процес управління ризиками, направлений на добросовісне виконання законодавства, норм етики, прийнятих у сфері регулювання правовідносин і принципів ділових відносин із метою підтримки належних правил і стандартів поведінки на ринку, а також підтримання іміджу установи, організації [7, с. 111].

Ю. Бондаренко зазначає, що «compliance - це невід'ємна частина корпоративної культури компанії, за якою виконання кожним співробітником власних посадових обов'язків, у тому числі прийняття рішень на всіх рівнях, повинно відповідати стандартам законності і сумлінності, встановленими компанією для ведення своєї діяльності» [8, с. 33].

Е. Нєізвєстна пропонує більш уточнене визначення комплаєнсу: «Комплаєнс - це сукупність вбудованих у кожний бізнеспроцес організації функцій, спрямованих на дотримання внутрішніх стандартів ведення бізнесу, корпоративної етики та законодавчих і нормативних вимог з метою досягнення найвищої ефективності фінансово-господарської діяльності» [9, с. 269].

С. Дж. Гріффіт наголошує, що «комплаєнс» - це сукупність внутрішніх процесів, за допомогою яких фірми адаптують свою поведінку до встановлених норм. Комплаєнс встановлює внутрішні механізми попередження та виявлення порушення законодавства і регуляторних практик [10].

У юридичній літературі по-різному визначаються поняття комплаєнсу, його цілі, функції, потенційні сфери застосування, наслідки впровадження та ін. Одні автори роблять акцент на здатності підприємця діяти відповідно до публічних вимог [11] i визначають комплаєнс як форму саморегулювання, що базується на державному ре- гулюванні суспільних відносин [12, с. 24], що відповідає встановленому керівництву, порядку, набору правил, вимогам, специфікаціям або законодавству [13, с. 10]; інші - на внутрішньому контролі (самоконтролі) підприємця, який визначається власними інтересами, що, зрозуміло, не виключає також облік вимог законодавства та наглядових органів [14, с. 48], як безперервну і специфічну діяльність 3 виявлення випадків та фактів невідповідності законам та вимогам, нормативно-правовим актам, ринковим стандартам і внутрішнім документам організації [15, с. 45] або як систему захисту бізнесу і його акціонерів від зовнішньої корупції, зловживань та неефективного управління організацією з боку іï топ-менеджерів, а також здатність діяти у відповідності з інструкціями, правилами і спеціальними вимогами [16, с. 242].

Як бачимо, із вищезазначеного комплаєнс не рідко застосовується у вузькому розумінні як функція внутрішнього контролю відповідної структурної одиниці суб'єкта господарювання щодо виявлення фактів порушення нормативних приписів [17, с. 6], як внутрішній механізм [18], або як система організаційно-правових або корпоративних заходів [19.. Більш розширене розуміння, проте, яке, на нашу думку, не повністю охоплює розуміння комплаєнсу, пропонується Рубцовою Н.В. та визначається як попередження виникнення порушень антимонопольного законодавства, забезпечення відповідності діяльності суб'єкта підприємницької діяльності вимогам, обов'язковим для виконання, які встановлені чинним законодавством і локальними актами цього суб'єкта, з метою забезпечення безпеки держави і суспільства, а також підвищення конкурентоспроможності господарюючого суб'єкта [20, с. 32].

у цілому, слід зазначити, що базисом, який опосередковує організаційно-правові та методологічні вимоги до впровадження комплаєнсу, є як законодавчі акти загальної дії, так і регуляторні (наприклад, Сарбайнс-Окслі, Базель II, НIPAА), стандартів та кодексів практики (наприклад, SCOR, ISO9000), договорів 3 діловими партнерами [21], а також корпоративних (вну- 
трішніх) правил локальної дії (наприклад, етичних норм поведінки, що $є$ усталеною та відповідає певній сфері діяльності).

Таке дотримання правових норм і вимог законодавства, стандартів та етичних норм (кодексів поведінки) може стосуватися, зокрема: протидії корпоративному шахрайству та корупції (антикорупційний комплаєнс), антимонопольного регулювання (антимонопольний коплаєнс), захисту персональних даних, корпоративних відносин тощо.

Як зазначають Попондопуло В.Ф. та Петров Д.А., у юриспруденції можливість застосування комплаєнс-процедур може бути реалізована в різних сферах: антимонопольної; екологічної; аудиторської діяльності; корпоративної; податкової; технічного регулювання; стандартизації; державного управління; фінансового ринку; протидії легалізації (відмиванню) доходів, одержаних злочинним шляхом, і фінансуванню тероризму; використання об'єктів інтелектуальної власності; трудових відносин; антикорупційного регулювання; здійснення публічних і корпоративних закупівель та ін. [22, с. 105].

Вищезазначені нами погляди щодо визначення комплаєнсу утверджують нашу позицію щодо виділу «уніфікованих» видів комплаєнсу, які необхідні для будь-якої організації (антикорупційний, податковий, корпоративний, трудовий комплаєнс) та інших вузькопрофільних видах комплаєнсу, що знаходяться у безпосередній залежності від специфічних особливостей діяльності суб'єкта господарювання (комплаєнс у сфері протидії легалізації (відмиванню) доходів, що одержані злочинним шляхом, комплаєнс у сфері протидії фінансування тероризму, комплаєнс у сфері фінансової та банківської діяльності, комплаєнс у сфері інтелектуальної власності та інновацій та ін.).

Так, пропонуємо виділити наступні види комплаєнсу поділивши їх на два munu:

1. Види комплаєнсу необхідні для будь-якого суб'єкта господарювання:

- антикорупційний комплаєнс;

- податковий комплаєнс;
- корпоративний комплаєнс;

- трудовий комплаєнс.

2. Види комплаєнсу залежності від специбіки здійснення підприємницької діяльності:

- комплаєнс в сфері протидії легалізації (відмиванню) доходів, що одержані злочинним шляхом;

- комплаєнс у сфері протидії фінансування тероризму;

- комплаєнс у сфері фінансової та банківської діяльності;

- комплаєнс у сфері інтелектуальної власності та інновацій

- екологічний коплаєнс;

- антимонопольний комплаєнс;

- страховий комплаєнс;

- комплаєнс у сфері ринку цінних паперів;

- комплаєнс в сфері лістингу та бірж;

- інші види залежно від специфіки здійснення підприємницької діяльності.

На цей момент слід мати на увазі серйозне упущення законодавця, який не визначив обов'язкове застосування комплаєнс-заходів на імперативному рівні. Відповідно, будь-який суб'єкт господарювання може на диспозитивному рівні визначати необхідність застосування комплаєнс-заходів залежно від сфери своєї діяльності та брати на себе відповідальність виявлення потенційно небезпечних можливих ризиків та наслідку їх проявів.

Проте, така диспозитивність у застосуванні комплаєнс-заходів власно суб'єктом господарювання жодним чином не впливає на його презумпцію винуватості.

Передбачаючи можливість імперативного відображення в законі застосування комплаєнс-заходів кожним суб'єктом господарювання, слід погодитись 3 тим, що винятковий перелік таких комплаєнс-заходів навряд чи буде міститись у законі, адже їх деталізація все одно буде обов'язком суб'єкта господарювання. Це є логічним 3 огляду на те, що така деталізація можливих імперативних комплаєнс-заходів $\epsilon$ необхідною 3 огляду на особливості внутрішньої організації, статутних документів та специфіки діяльності.

У цьому сенсі комплаєнс-заходи відносяться до заходів внутрішнього контролю. 
Таким чином, можна казати про те, що комплаєнс входить до системи заходів щодо управління ризиками.

Вважаємо, що в контексті зазначеного слід деталізувати поняття ризику.

Розуміючи ризик як виникнення факту об'єктивної дійсності, слід зазначити, що цей факт має бути пов'язаний 3 певною дією або подією, що, відповідно, знаходить своє відображення в теорії юридичної науки і підпадає під поняття юридичного факту, юридичного складу або складного юридичного складу. Разом з тим класифікація вищезазначених юридичних фактів по відношенню до комплаєнс-ризиків має враховувати особливості впливу, що викликані зовнішніми або внутрішніми факторами. Ці відмінності мають значний вплив при визначенні комплаєнс-ризиків і особливо тих, що мають у своїй природі зовнішню складову - незалежну від суб'єкта господарювання. До таких зовнішніх факторів слід віднести обставини непереборної сили (у широкому розумінні їх правового тлумачення), а також зміна законодавства, що безпосередньо може впливати на виникнення комплаєнс-ризиків. Таке виокремлення комплаєнс-ризиків «зовнішнього» походження може розглядатись як поштовх до ініціації специфічного виду комплаєнс-заходів, що мають бути націлені на виявлення та попередження наслідків обумовлених тенденціями як наявних так і прогнозованих зовнішніх факторів. Такі зовнішні фактори можуть бути проявом наслідків нестабільної політичної ситуації, впливу корупційних ризиків олігархічних структур, кризових явищ в економіці, наслідків пандемії, девальваційних та інфляційних процесів, воєнних дій.

Вищезазначене повністю відповідає та знаходиться в контексті етимологічного розуміння словосполучення «комплаєнсризик», що може охоплювати негативні наслідки різних сфер соціально-правового впливу (від цивільно- та господарсько-правової до адміністративно- та кримінальноправової відповідальності та покладення різного роду ущемлень на суб'єкта господарювання у вигляді штрафних, оперативно-господарських та адміністративно-гос- подарських санкцій, а також втрат немайнового характеру в тому чи іншому співвідношенні.

Висловлена вище наша позиція щодо обумовлення комплаєнс-ризиків наявністю юридичних фактів зовнішнього та внутрішнього походження частково знаходить своє відображення та підтримується в науковій літературі [23].

Разом $з$ тим, слід зазначити, що в науково-практичній літературі знаходить своє відображення і більш вузьке розуміння комплаєнс-ризиків - ризики виникають при недотриманні законодавчих норм і пов'язані $з$ визначенням кола заходів, а також оцінкою негативних впливів несвоєчасного, неповного, не відповідного суті виконання регулятивів різного рівня.

3 метою звернення уваги на необхідності аналізу широкого спектру видів комплаєнсу пропонуємо дати визначення тим видам комплаєнсу, що є необхідними для будь-якого суб'єкта господарювання.

Антикорупиійний комплаєнс.

Під антикорупційним комплаєнсом розуміють систему заходів, що застосовується на підприємстві, в установі чи організації 3 метою запобігання вчинення їх працівниками чи керівництвом корупційних та пов'язаних з ними правопорушень, а також 3 метою забезпечення відповідності діяльності підприємства, установи, організації вимогам антикорупційного законодавства $[24$, c. 4$]$.

Мета антикорупційного комплаєнсу не дозволяти співробітникам порушувати норми та приписи щодо боротьби з корупцією. I, звичайно, виявляти реальні факти корупції в компанії.

Антикорупційний комплаєнс $є$ доволі ефективним засобом запобігання корупції у приватній сфері. Але його впровадження в українських компаніях із низки причин стало лише формальною процедурою, що потребує подальшого удосконалення. Розширення практики антикорупційного комплаєнсу - це не єдиний, але обов'язковий крок до подолання корупції у приватній сфері.

Вимушені констатувати, що такий дієвий вид комплаєнсу, як «антикорупцій- 


\section{Цивільне, підприємницьке, господарське та трудове право}

ний», що довів свою ефективність в економічно розвинутих країнах, в Україні носить формальний вигляд, у першу чергу, 3 огляду на результати подолання корупції у сфері господарювання, і відповідно потребує дослідження механізмів його подальшого удосконалення та практики застосування. При цьому, головною метою «антикорупційного комплаєнсу» має бути ефективне запобігання вчиненню корупційних порушень та своєчасне виявлення фактів корупції на всіх ланках суб’єкта господарювання.

На підставі вищезазначеного пропонуємо власне визначення антикорупційного комплаєнсу.

Антикорупційним комплаенсом є комплекс заходів, що визначається внутрішніми приписами суб'єкта господарювання з метою забезпечення відповідності його діяльності вимогам антикорупційного законодавства та унеможливлення вчинення посадовими особами відповідного суб'єкта господарювання корупційних правопорушень.

Податковий комплаєнс.

Податковий комплаєнс - комплекс мотивів та стимулів платників, які спонукають їх дотримуватися вимог податкового законодавства, законодавства із сплати єдиного внеску на загальнообов'язкове державне соціальне страхування та сплачувати податки, збори, платежі [25].

Податкова політика як один із основних напрямів економічної політики держави, про що йдеться у ст. 10 Господарського кодексу України від 16 січня 2003 р. № 436-IV, [26] спрямована на забезпечення економічно обгрунтованого податкового навантаження на суб'єктів господарювання, стимулювання суспільно необхідної економічної діяльності суб'єктів, а також дотримання принципу соціальної справедливості та конституційних гарантій прав громадян при оподаткуванні їх доходів.

Запровадження системи податкового комплаєнсу дасть змогу вивести відносини iз платниками на зовсім новий рівень, що грунтується на довірі та партнерстві. Система податкового комплаєнсу дасть змогу мінімізувати ризики недотримання платниками вимог податкового законодавства, допомогти платникам уникнути найбільш поширених помилок у майбутньому, максимально спростити подання звітності та сплату податків, спільно вирішувати проблеми й усувати перешкоди в забезпеченні податкової безпеки.

Аналіз публічної інформації забезпечення своєчасності сплати податків в Україні дозволяє зробити висновок про незадовільний стан справи. Податковий комплаєнс може розглядатись як один 3 дієвих стимулів недотримання платниками вимог податкового законодавства та очікувано дозволить оптимізувати ризики несплати податків шляхом спрощення подання податкової звітності та уникнення найбільш розповсюджених помилок, у наслідок чого може виконувати важливу соціоекономічну роль забезпечення сталого розвитку держави.

Так, пропонуємо податковий комплаєнс визначити наступним чином: Податковим комплаенсом є комплекс заходів, що визначається внутрішніми приписами суб'єкта господарювання з метою забезпечення відповідності його діяльності вимогам податкового законодавства та запобігання вчинення посадовими особами відповідного суб'єкта господарювання податкових правопорушень при стягненні обов'язкових податків, зборів та платежів.

Корпоративний комплаєнс:

Корпоративний комплаєнс є достатньо широким поняттям та не має чітких окреслених меж. Поряд із Кодексом корпоративної поведінки ним охоплюється політика, що регулює конфлікт інтересів завдяки впровадженню етичних стандартів поведінки співробітників у разі виникнення подібних конфліктів (інтереси посадової особи вступають у протиріччя 3 інтересами суб'єкта господарювання, інтересами одного з клієнтів тощо); політика інформування про порушення етичних стандартів (whistleblowing policy), що надає можливість працівникам як офіційно, так i анонімно повідомляти про випадки корупції та інших порушень норм і стандартів поведінки; політика чесної конкуренції, що вимагає від кожного співробітника виконання конкурентних правил та умов та 
направлена на формування вільного ринку та відкритої конкуренції товарів та послуг тощо.

Корпоративний комплаєнс - це діяльність, пов'язана $з$ контролем за дотриманням посадовими особами та працівниками вимог законодавства та локальних актів нормативного та ненормативного характеру в господарських товариствах.

Аналіз ефективності застосування комплаєнс компаніями в економічно розвинутих країнах свідчить про важливість виокремлення такого виду, як «корпоративний» комплаєнс, що може охоплювати різнопланові заходи, що $є$ актуальними для окремо визначеного суб'єкта господарювання та можуть включати: політику корпоративної поведінки, етичні стандарти поведінки працівників певної сфери, політику чесної конкуренції тощо. Зазначена форма внутрішнього контролю у своєму застосуванні серед суб'єктів господарювання в Україні стикається з низкою суб'єктивних перепон, серед яких найбільш розповсюдженими вважаються:

- недосконалість законодавства, що дозволяе доволі часто уникати відповідальності при ліквідації суб'єкта господарювання, коли протиправні дії керівництва спричинили втрату ділової репутації юридичної особи;

- недосконалості законодавства щодо кримінальної відповідальності посадових осіб при здійсненні господарської діяльності за законодавством України;

- особливостями ментального ставлення до комплаєнс заходів у цілому, як до нової, додаткової форми внутрішнього контролю.

Так, корпоративним комплаенсом є комплекс заходів, що визначається внутрішніми приписами суб'єкта господарювання 3 метою забезпечення відповідності його діяльності вимогам Украӥнсъкого законодавства та запобігання вчинення посадовими особами відповідного суб'єкта господарювання порушень законів, норм та правил, що є обов'язковими для відповідної сбери діяльності, а також локальних актів внутрішнвого значення при здійсненні господарської діяльності.

Трудовий комплаєнс.
Актуальність цього виду комплаєнсу прямо пропорційна кількості співробітників компанії. Хоча контролювати дотримання трудового права необхідно будьякому підприємству. Просто у великих колективах складніше «стежити» за всіма i запобігати порушенням, а отже - конфліктним ситуаціям зі співробітниками.

Завдання фахівців 3 трудового комплаєнсу - запобігання порушенням трудового законодавства компанією і співробітниками, розгляд скарг і заяв від співробітників, робота над внутрішньою політикою стосовно кадрових питань. Іноді великі компанії вдаються до послуги кадрового аудиту, щоб перевірити якість дотримання трудового законодавства [27].

Комплаєнс для трудового права в Україні є повністю новим поняттям, проте правовий розвиток держави, інтеграція в EС потребує створення цього інституту вже тут і зараз. Трудовий комплаєнс є досить популярним за кордоном, у США та Великобританії обов'язковим є наявність запроваджених в установах, підприємствах та організаціях програм комплаєнсу, оскільки це 6 одним 3 показників надійності цього суб'єкта на ринку праці. Глава XVIII Кодексу законів про працю України [28] встановлюе норми, що здійснюють нагляд і контроль за додержанням трудового законодавства, передбачаючи здійснення контролю центральними органами виконавчої влади за додержанням законодавства про працю на підприємствах, в установах і організаціях, що перебувають у їх функціональному підпорядкуванні, крім органів доходів і зборів, які мають право 3 метою перевірки дотримання податкового законодавства здійснювати такий контроль на всіх підприємствах, в установах i організаціях незалежно від форм власності та підпорядкування [29, с. 153], з чого можна зробити висновок, що підприємство має належний зовнішній контроль 3 боку держави, але позбавлене внутрішнього.

Дослідження комплаєнс-заходів, що застосовуються зарубіжними компаніями, дозволяє дійти висновку про необхідність виділення трудового комплаєнсу як окремого виду комплаєнсу за своїм функ- 


\section{Цивільне, підприсмницьке, господарське та трудове право}

ціональним значенням та важливістю. Цей вид комплаєнсу може включати так званий «кадровий аудит», проте у своєму функціональному значенні має забезпечувати більш широкий спектр внутрішнього контролю, як-от то кадрова політика підприємства, розгляд скарг, планування «кадрового резерву» та інші напрями, важливість яких, у свою чергу, знаходиться у прямій залежності від масштабів суб'єкта господарювання та сфери діяльності.

Спираючись на вищезазначене, можна запропонувати наступне визначення трудовому комплаєнсу: Трудовим комплаєнсом є комплекс заходів, що визначається внутрішніми приписами суб'єкта господарювання з метою забезпечення відповідності його діяльності вимогам трудового законодавства та запобігання вчинення посадовими особами та працівниками відповідного суб'єкта господарювання порушень законів про працю, норм техніки безпеки та правил, що є обов'язковими для відповідної сбери діяльності, а також локальних актів внутрішнъого значення при здійсненні господарсъкої діяльності.

\section{Література}

1. Українська Вікіпедія. URL: https:// uk.wikipedia.org/wiki/\%D0\%9A\%D0\% BE\%D 0\%BC\%D0\%BF\%D0\%BB\%D0\%B $0 \% \mathrm{D} 1 \% 94 \%$ D0\%BD\%D1\%81

2. Оксфордський словник англійської мови. URL: https://oxforddictionaries.com

3. Compliance. Cambridge Dictionary Online. URL: https:// dictionary.cambridge. org/dictionary/english/compliance

4. Гелеверя В. В., Хуторна М. Е. Організація ефективної системи комплаєнсконтролю в банку. Фінансовий простір. 2015. № 2 (18). С. 113-119

5. Офіційний сайт Базельського комітету. URL: http://www.bis.org/bcbs/index.htm

6. Правдива $\lambda$. Удосконалення корпоративного управління в банках та управління комплаєнс-ризиком. Вісник НБУ. 2011. № 7. С. 10-13

7. Москаленко Н.В. Теоретичні аспекти запровадження комплаєнс-контролю в Україні. Економічний вісник. Серія : Фі- нанси, облік, оподаткування. 2018. Вип. 2. C. $106-112$

8. Бондаренко Ю. Эффективное управление compliance-рисками: системный подход и критический анализ. Корпоративный юрист. 2008. № 6. С. 31-34

9. Нєізвєстна О. В. Дослідження практики комплаєнс у страхових компаніях України. Актуальні проблеми економіки. 2017. № 3 (189). С. 267-273

10. Griffith Sean J. Corporate Governance in an Era of Compliance. William \& Mary Law Review. 2016. Vol. 57. No. 6; Fordham Law Legal Studies Research Paper. № 2766661. URL: https://ssrn.com/abstract $=2766661$

11. Малыхин Д. В. Особенности организации комплаенс-контроля в российских банках // Внутренний контроль в кредитной организации. 2009. № 2. URL: https://www.lawmix.ru/ bux/26031

12. Франскевич О.П. Комплаенс как форма саморегулирования. Юрист. 2018. № 1. С. 20-25.

13. Шарамко М. М. Институциональный комплаенс-контроль: монография. Москва: РУСАЙНС, 2016. 138 с.

14. Морковкина Е.Б. Комплаенс-функция в кредитных организациях. Бухгалтерия и банки. 2005. № 12. С. 47-49

15. Беляев Ю. К. Применение инструментов комплаенс-контроля для оптимизации корпоративного управления фармацевтическими компаниями. Известия УрГӘУ . 2013. №1 (45). С. 45-50

16. Калініченко $\mathcal{\lambda}$. $\mathcal{\Lambda}$. Теоретичні аспекти функціонування комплаєнсу у вітчизняних банках. Наук. вісн. Херсон. держ. унту. Серія Економічні науки. Вип. 6. Ч. 4. 2014. С. 242-245

17. Иванова Ж.Б. Комплаенс и отношения права собственности субъектов предпринимательства на объекты культурного наследия. Юрист. 2017. № 18. С. 4-8

18. Щерба Т.Ә. 2018. Антимонопольный комплаенс в России. Понятие. Виды. СПС «КонсультантПлюс». Из информационного банка «Юридическая преcca». URL: http://www.consultant.ru/ cons/cgi/online.cgi? req =doc\&base $=\mathrm{CJI}$ $\underline{\& n}=114259 \# 06979309333207595$ 
19. Что такое антимонопольный комплаенс? Конкуренция и право. 2014. URL: http://www.cljournal.ru/vibor/118

20. Рубцова Н.В. Комплаенс как модель нормативного регулирования предпринимательской деятельности». Юрист. 2017. № 18. C. 30-33

21. Fiene, Richard (2016), Theory of Regulatory Compliance. DOI: 10.13140/ RG.2.2.34971.67360

22. Попондопуло В.Ф., Петров Д.А. Комплаенс как правовой инструмент минимизации рисков и профилактики правонарушений. Вестник СанктПетербургского государственного университета. Право. 2020. № 1. C 102-114

23. Николаева А.А. Реализация комплаенс-функции в промышленности. URL: https://cyberleninka.ru/article/n/realizatsiyakomlpaens-funktsii-v-promyshlennosti

24. Методичні рекомендації щодо розробки та впровадження системи заходів щодо запобігання та протидії корупціï. URL: http://cgpa.com.ua/wp-content/ uploads/images/files/methodologicalrecommendations-for-anticorrption-policy. doc

25. У ДФС розпочато підготовку Комплаєнс стратегіï. URL: http://sfs.gov.ua/mediatsentr/novini/386784.html

26. Господарський кодекс України: від 16 січ. 2003 р. № 436-IV (зі змінами). URL: http://zakon2.rada.gov.ua/laws/show/436-15

27. Види комплаєнсу і коли він може знадобитися. URL: https://youcontrol.com. ua/articles/compliance guide/

28. Кодекс законів про працю України: від 17 груд. 1971 р. № 322-VIII (зі змінами). URL: https://zakon.rada.gov.ua/laws/ show/322-08\#Text

29. Романчик Т. В. Місце комплаєнс у забезпеченні економічної безпеки підприємства. // Актуальні питання організації та управління діяльністю підприємств у сучасних умовах господарювання : зб. тез доп. 7-ї наук.-практ. конф., 29 листопада 2017 р., м. Харків : електрон. вид. [Харків : НАНГУ, 2017]. С. 152-154.

Mykyta Mozharovskyi

\section{THEORETICAL AND LEGAL ANALYSIS OF "COMPLIANCE" DEFINITION AND ITS TYPES}

The article is devoted to theoretical and legal analysis of the concept of "compliance" depending on its specific features, which are the basis of industry affiliation as the most common and widely used mechanisms of internal control of a business entity in modern conditions in Ukraine.

The Author notes that a well-known fact, supported by the vast majority of both scientists and practitioners, is a direct relationship between expected profitability (which is usually embedded in the technical and economic performance of the business) and possible risks when doing business.

It is stated that the presence of both subjective and objective factors existing in modern conditions in Ukraine should be taken into account when determining such a ratio. Author states that such factors as instability of the political situation, the impact of corruption risks, economic crises, including the impact of the Covid-19 pandemic, the devaluation of the national currency and, above all, the war in eastern Ukraine influence randomness of business.

According to the Author, measures aimed on improving the culture of corporate governance can prevent this, which, first of all, should include compliance measures aimed at compliance with generally accepted norms, anti-corruption legislation, rules that are generally accepted in the relevant field of management. , which together should ensure the stability of activities in the existing conditions and non-elimination of negative factors.

Compliance measures, which have been widely used for a long time by companies of economically developed countries, are beginning to be implemented by domestic economic entities in their activities and serve as an important element of integration of Ukrainian companies into the world economy.

Emphasis is placed on the importance of compliance for the sustainable development of Ukraine's economy and concludes on the importance of the existence of such components in the activities of any compliance department as prior consistency of regulations and algorithms aimed at identifying, identifying, assessing and avoiding timely risks.

It is noted that compliance measures may have their own specifics of their application in a fairly wide range of socio-economic relations. This range is not limited to the areas of anti-corruption, tax, corporate, labor, but is quite relevant in the applica- 


\section{Цивільне, підприсмницьке, господарське та трудове право}

\section{АНОТАЦІЯ}

Стаття присвячена теоретико-правовому аналізу поняття «комплаєнс» залежно від його видових ознак, що лежать в основі галузевої приналежності як найбільш розповсюджених та широко застосовуваних механізмів внутрішнъого контролю суб'єкта господарювання в сучасних умовах в Украӥні.

Ключові слова: комплаєнс, комплаєнс-ризики, коплаєнс-процедури, антикорупщійний комплаєнс, податковий комплаєнс, корпоративний комплаєнс, трудовий комплаєнс, комплаєнс-норми, комплаєнс-контроль, суб'єкти господарювання.

tion of antitrust, innovation, intellectual property, ecology, technical regulation and standardization and. etc.

The views of scientists on the definition of compliance confirmed the author's position on the selection of "unified" types of compliance that are necessary for any organization (anti-corruption, tax, corporate, labor compliance) and other narrow types of compliance that are directly dependent on the specific characteristics of the business entity (compliance in the field of combating legalization (laundering) of proceeds from crime, compliance in the field of combating terrorist financing, compliance in the field of financial and banking activities, compliance in the field of intellectual property and innovation, etc.).

It is proposed to distinguish the types of compliance by dividing them into two types (types of compliance required for any business entity and types of compliance depending on the specifics of business).

Keywords: compliance, compliance risks, compliance procedures, anti-corruption compliance, tax compliance, corporate compliance, labor compliance, compliance requirements, compliance control, business entities. 